\title{
Disease resistance to bacterial pathogens affected by the amount of ferredoxin-I protein in plants
}

\author{
HSIANG-EN HUANG ${ }^{1}$, MANG-JYE GER ${ }^{2}$, CHAO-YING CHEN ${ }^{3}$, AJAY-KUMAR PANDEY ${ }^{1}$, MEI-KUEN \\ YIP1, HUNG-WEN CHOU ${ }^{1}$ AND TENG-YUNG FENG ${ }^{1, *}$ \\ 1 Institute of Plant and Microbial Biology, Academia Sinica, Nankang, Taipei 115, Taiwan \\ 2 Department of Life Science, National University of Kaohsiung, Kaohsiung 811, Taiwan \\ ${ }^{3}$ Department of Pathology and Microbiology, National Taiwan University, Taipei, 106, Taiwan
}

\section{SUMMARY}

Ferredoxin-I ( $\mathrm{Fd}-\mathrm{I})$ is a fundamental protein that is involved in several metabolic pathways. The amount of Fd-I found in plants is generally regulated by environmental stress, including biotic and abiotic events. In this study, the correlation between quantity of $\mathrm{Fd}-\mathrm{I}$ and plant disease resistance was investigated. Fd-I levels were increased by inoculation with Pseudomonas syringae pv. syringae but were reduced by Erwinia carotovora ssp. carotovora. Transgenic tobacco over-expressing Fd-I with the sense sweet pepper $\mathrm{Fd}$-I gene ( $p f \mathrm{l}$ ) was resistant to $E$. carotovora ssp. carotovora and the saprophytic bacterium P. fluorescens. By contrast, transgenic tobacco with reduced total $\mathrm{Fd}-\mathrm{I}$ and the antisense pflp gene was susceptible to E. carotovora ssp. carotovora and $P$. fluorescens. Both of these transgenic tobaccos were resistant to $P$. syringae pv. syringae. By contrast, the mutated $E$. carotovora ssp. carotovora, with a defective harpin protein, was able to invade the sense-pflp transgenic tobacco as well as the non-transgenic tobacco. An in vitro kinase assay revealed that harpin could activate unidentified kinases to phosphorylate PFLP. These results demonstrate that $\mathrm{Fd}-\mathrm{I}$ plays an important role in the disease defence mechanism.

\section{INTRODUCTION}

A sweet pepper ferredoxin-I (Fd-I) protein (PFLP) that is associated with the production of active oxygen species (AOS) and the hypersensitive reaction (HR) has been identified (Dayakar et al., 2003). Fd-I, which confers a highly negative redox potential from 350 to $450 \mathrm{mV}$, transfers electrons from photosystem I (PSI) to the enzyme Fd:NADP+ ${ }^{+}$oxidoreductase for photoreduction of NADP+ via linear electron flow (Arnon, 1989; Joliot and Joliot, 2006; Morales

* Correspondence: Tel.: +886 2 26521867; Fax: +886 22782 7954;

E-mail: mpmi224@gate.sinica.edu.tw et al., 2002). According to this reaction, Fd-I is involved in several important metabolic pathways such as photosynthesis, nitrate reduction and lipid synthesis (Curdt et al., 2000; Geigenberger et al., 2005; Hanke et al., 2004; Meyer, 2001).

$\mathrm{Fd}-\mathrm{I}$ generally exists in all green tissues of plants and shows little diversity in different plant species. For example, the pflp gene shares $81.2 \%$ identity in amino acid sequence and $80.4 \%$ identity in nucleotide sequence with the Fd-I gene of Nicotiana tabacum, fdn-I (accession no. AY552781). Fd-I also has multiple iso-proteins that are unique in both amino acid sequence and in their biochemical characteristics in different tissues (Bertini et al., 2002; Green et al., 1991). For example, Fd-II, which usually accompanies $\mathrm{Fd}-\mathrm{I}$, is able to transfer electrons via cyclical electron flow in the mesophyll chloroplast (Kimata and Hase, 1989; Kimata et al., 2000; Matsumura et al., 1999). Fd-III exists specifically in the root tissue of plants (Hanke et al., 2004; Onda et al., 2000) and Fd-IV, which shares a similar amino acid sequence with Fd-III, is induced by nitrate (Hanke et al., 2004).

The amount of $\mathrm{Fd}$-I protein in plants is regulated by their environment. For example, the quantity of $\mathrm{Fd}$-I is up-regulated by light and the availability of carbon, but down-regulated by $\mathrm{H}_{2} \mathrm{O}_{2}$, heavy metals and senescence (Elliott et al., 1989; John et al., 1997; Mazouni et al., 2003; Vorst et al., 1993). Recently, the expression profiles of photosynthesis-associated proteins in response to the inoculation of bacteria were studied. For example, Fd-I mRNA expression was down-regulated following inoculation with transgenic Pseudomonas syringae pv. glycinea, which carries the avirulent gene avrB to induce an HR in potato (Zou et al., 2005). The amount of mRNA from photosynthesis-associated proteins in tobacco was also reduced by another biotic event, knockout of the nbpaf gene, which encodes the $\alpha 6$ subunit of 205 proteasome. However, in some cases it was increased by incompatible pathogens that induce HR in plants, such as $P$. syringae pv. syringae 61, when inoculated in tobacco (Kim et al., 2006).

The over-expression of PFLP in transgenic plants, such as tobacco, rice and orchid, enhances plant resistance to bacterial pathogens (Huang et al., 2004; Liau et al., 2003; Tang et al., 
2001). It is therefore hypothesized that the quantity of total Fd-I is important for plants to activate defence mechanisms. To examine this hypothesis, total Fd-I was changed by over-expression of the sense and antisense pflp gene in transgenic tobaccos. These transgenic tobaccos were then inoculated with different bacterial pathogens to study the role of $\mathrm{Fd}-\mathrm{I}$ in plant defence.

Many kinases, such as AtMPK4 and AtMPK6, are activated in harpin-treated plants (Adam et al., 1997; Desikan et al., 2001; Samuel et al., 2005). Casein kinase II (Ck2), which can phosphorylate the defence-associated element TGA transcriptional factor, was also activated by salicylic acid in arabidopsis (Kang and Klessig, 2005). PFLP possesses a putative Ck2 phosphorylation site with the general consensus sequence S/TXXD/E in the carboxylterminal region. It is able to intensify the HR activated by harpin (Dayakar et al., 2003). To understand the relationship between PFLP and harpin in plant defence, the phosphorylation of PFLP by certain kinases activated by harpin was studied in vitro.

\section{RESULTS}

\section{The quantity of Fd-I protein in pathogen-inoculated tobacco leaf}

The quantity of $\mathrm{Fd}-\mathrm{I}$ in tobacco can be estimated by Western blotting with a polyclonal antiserum against PFLP. To investigate variations in $\mathrm{Fd}-\mathrm{I}$ in response to bacterial pathogen, crude proteins of inoculated leaves were extracted and then estimated by Western blotting. The quantity of Fd-I was 1.5 -fold increased by inoculation with $P$. syringae pv. syringae in tobacco at $4 \mathrm{~h}$ post-inoculation (hpi) and 3-fold increased at $24 \mathrm{hpi}$. By contrast, it was reduced by inoculation of $E$. carotovora ssp. carotovora at $4 \mathrm{hpi}$ and undetectable at $8 \mathrm{hpi}$. Treatment with $10 \mathrm{~mm}$ phosphate buffer was used as a control (Fig. 1).

\section{Generation of transgenic tobacco containing various amounts of PFLP}

To create a transgenic tobacco with variable levels of $\mathrm{Fd}-\mathrm{I}$, sense and antisense pflp genes were over-expressed in the transgenic tobaccos with the $35 \mathrm{~S}$ CaMV promoter. The total amount of Fd-I in the transgenic tobaccos was estimated by Western blotting with antiserum against PFLP. This antiserum was prepared in a previous study and was able to recognize both PFLP and native Fdn-1 in the same position using SDS-PAGE because both have similar 144-amino-acid residues. The total amount of Fd-I protein in sense pflp-transgenic tobacco lines generated, T-SPFLP-10 and T-SPFLP-18 (Huang et al., 2004), increased by 3.13- and 2.80fold, respectively, as compared with non-transgenic tobacco. The antisense pflp-transgenic tobacco lines T-anti-SPFLP74 and Tanti-SPFLP34 possess only 52 and $47 \% \mathrm{Fd}-\mathrm{I}$, respectively, as compared with the non-transgenic plant (Table 1).

Plant size was also compared between non-transgenic and transgenic tobaccos. Sense pflp-transgenic lines T-SPFLP-10 and T-SPFLP-18 have a similar seedling size after 1 month; however, the size of the antisense pflp-transgenic line was reduced (Table 1). Photographs of transgenic and non-transgenic tobacco plants were taken 1 month post-planting (Fig. 2).

Table 1 Characterization of pflp-transgenic tobacco.

\begin{tabular}{llll}
\hline & & \multicolumn{2}{l}{ Size of plant } \\
\cline { 3 - 4 } Plant line & $\begin{array}{l}\text { Total Fd-I level } \\
(\text { fold change) }\end{array}$ & $\begin{array}{l}\text { Seedling length } \\
(\mathrm{mm}) \dagger\end{array}$ & $\begin{array}{l}\text { Leaf length } \\
(\mathrm{mm}) \neq\end{array}$ \\
\hline Wt & $1.00 \pm 0.21$ & $26.1 \pm 1.71$ & $85.53 \pm 5.65$ \\
T-SPFLP-10 & $3.13 \pm 0.21$ & $25.4 \pm 1.35$ & $86.63 \pm 5.66$ \\
T-SPFLP-18 & $2.80 \pm 0.58$ & $23.6 \pm 2.36$ & $87.11 \pm 7.01$ \\
T-anti-SPFLP 74 & $0.52 \pm 0.14$ & $23.1 \pm 1.84$ & $68.82 \pm 6.71$ \\
T-anti-SPFLP 34 & $0.47 \pm 0.16$ & $22.5 \pm 2.51$ & $70.35 \pm 3.22$ \\
\hline
\end{tabular}

${ }^{*}$ Total proteins of non-transgenic (Wt), sense-pflp (T-SPFLP-10, T-SPFLP-18) and anti-pflp (T-anti-SPFLP74, T-anti-SPFLP34) plants were extracted and detected with antiserum against PFLP. Total Fd-I levels of these plants were compared with non-transgenic tobacco, given the value 1 .

tPlants were grown in pots for 2 weeks and seedling length was measured. Mean seedling length was calculated from 20 plants.

¥The leaf lengths of 4-week-old plants. The mean of four leaves from each plant were measured and 20 plants of each line were used.
$\mathbf{A}$
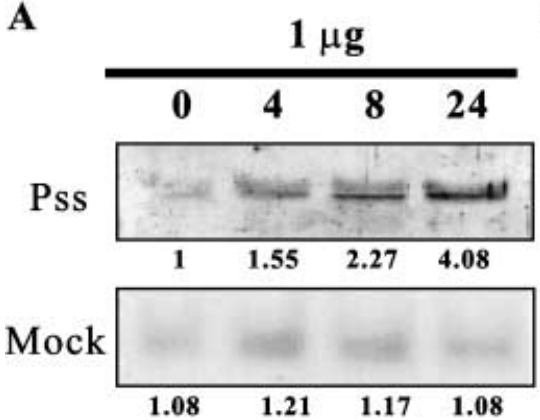

B

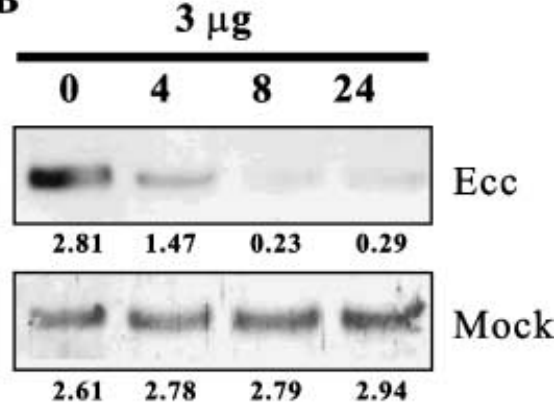

Fig. 1 The quantity of Fd-I in inoculated tobacco. Bacterial suspensions $\left(1.0 \times 10^{5} \mathrm{cfu} / \mathrm{mL}\right)$ of P. syringae pv. syringae (Pss) and E. carotovora ssp. carotovora (Ecc) were infiltrated into tobacco leaves, respectively. The total protein of the infiltrated area was extracted and analysed by Western blotting with antiserum against PFLP. One microgram of protein was used in Western blots of Pss-treated plants (A) and $3 \mu \mathrm{g}$ for Ecc-treated plants (B). Leaves treated with $10 \mathrm{~mm}$ phosphate buffer are indicated as Mock. Signal intensity is noted below. 
Fig. 2 The appearance of sense and antisense pflp-transgenic tobacco. The transgenic tobacco over-expressing the antisense (anti-pflp) and sense (sense-pflp) pflp gene and non-transgenic tobacco $(\mathrm{Wt})$ were planted in the growing chamber $\left(16 \mathrm{~h} \mathrm{light} / 8 \mathrm{~h}\right.$ dark at $30^{\circ} \mathrm{C}$ ) with irradiance of $48 \mu \mathrm{mol} / \mathrm{m}^{2} / \mathrm{s}$ for 1 month.

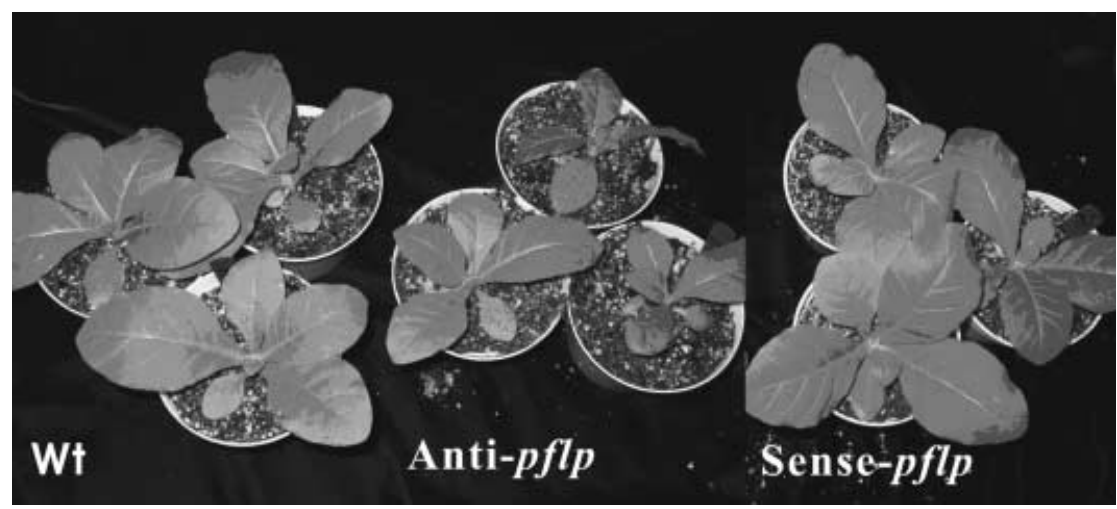

\section{pflp-transgenic plants inoculated with different bacteria}

Transgenic tobaccos with different amounts of total $\mathrm{Fd}-\mathrm{I}$ were challenged with different bacteria in order to study the role of FdI in plant defence. P. syringae pv. syringae, an avirulent pathogen of tobacco, did not cause any symptoms in detached leaf discs of sense, antisense pflp-transgenic and non-transgenic tobacco (Fig. 3A, upper panel). By contrast, E. carotovora ssp. carotovora caused softrot symptoms in detached leaf discs of non-transgenic tobacco and in antisense $p f l p$-transgenic tobacco, but not sense pflp-transgenic tobacco at 2 days post-inoculation (dpi) (Fig. 3A, lower panel).

The bacterial population in the inoculated plant was estimated. $P$. syringae pv. syringae was $<5.0 \times 10^{4} \mathrm{cfu}^{\mathrm{cm}} \mathrm{cm}^{2}$ in all antisense,
Fig. 3 Bacterial pathogen inoculated in pflptransgenic tobacco. Bacterial suspensions $\left(1.0 \times 10^{5} \mathrm{cfu} / \mathrm{mL}\right)$ of $E$. carotovora ssp. carotovora (Ecc) or $P$. syringae pv. syringae (Pss) were infiltrated into the leaf of sense-pflp, antipflp transgenic and non-transgenic tobacco $(\mathrm{Wt})$, respectively. The infiltrated area of individual plants was punched-out and placed in $10 \mathrm{~mm}$ phosphate buffer ( $\mathrm{pH} 7.0$ ) for 2 days (A). The bacterial populations in the inoculated plant were detected on 0, 1 and 3 days post-inoculation. All values represent means of 16 replications with standard deviations shown as error bars (B).

\section{A Anti-pflp}
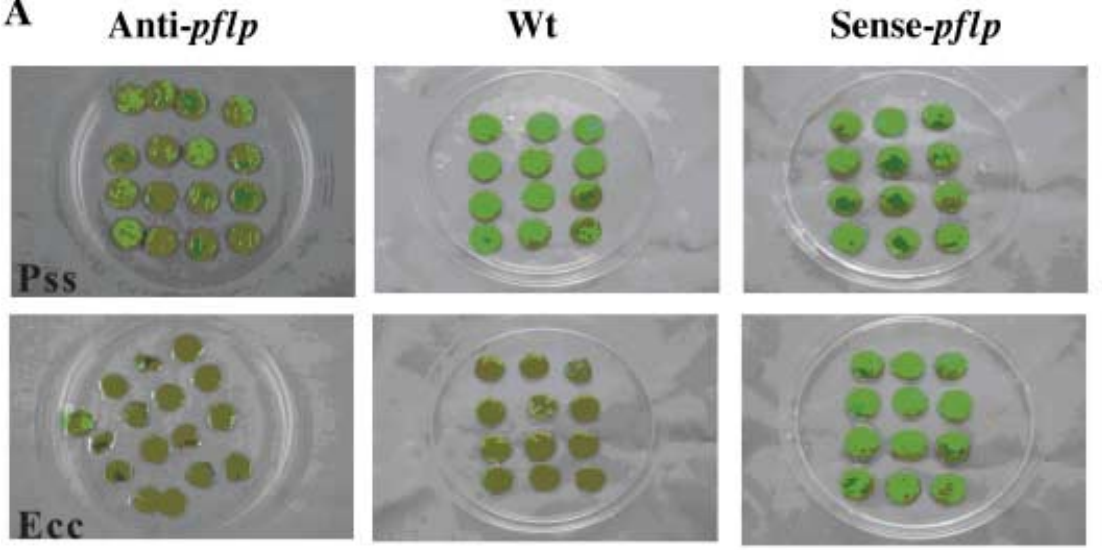

\section{B}

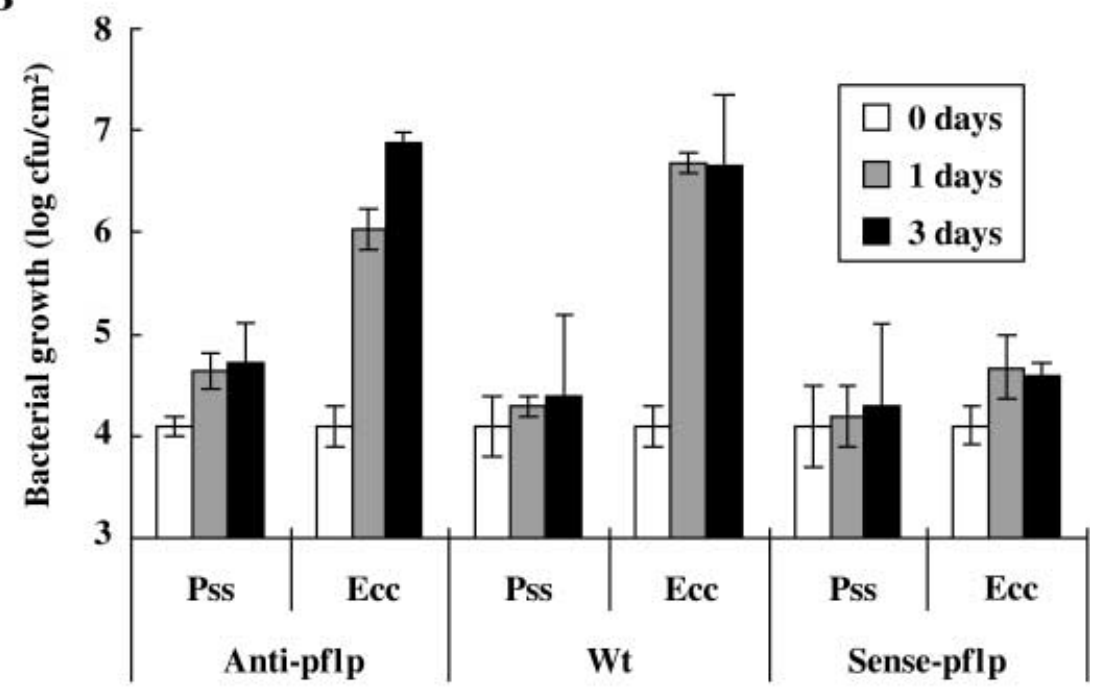


sense pflp-transgenic and non-transgenic lines. By contrast, E. carotovora ssp. carotovora was $<5.0 \times 10^{4} \mathrm{cfu} / \mathrm{cm}^{2}$ only in the sense pflp-transgenic tobacco but was increased to $1.0 \times 10^{7} \mathrm{cfu} /$ $\mathrm{cm}^{2}$ in the antisense pflp-transgenic and non-transgenic line at $3 \mathrm{dpi}$ (Fig. 3B). These results demonstrate that the sense but not antisense pflp-transgenic plant is resistant to $E$. carotovora ssp. carotovora. By contrast, both sense and antisense pflp-transgenic plants are resistant to $P$. syringae pv. syringae.

Levels of total Fd-I protein in bacterial inoculated transgenic tobacco were estimated to study its effect on plant disease resistance. Following inoculation with $P$. syringae pv. syringae, total $\mathrm{Fd}$-I was increased threefold in antisense pflp-transgenic tobacco and twofold in sense pflp-transgenic tobacco at 24 hpi (Fig. 4A). By contrast, total $\mathrm{Fd}-\mathrm{I}$ was reduced by $25 \%$ in antisense transgenic tobacco inoculated with $E$. carotovora ssp. carotovora but not in sense pflp-transgenic tobacco at $24 \mathrm{hpi}$ (Fig. 4B).

The transgenic tobacco lines were also challenged with the saprophytic bacterium $P$. fluorescens AZS1 (Pf-AZS1), which is unable to grow inside non-transgenic tobacco. Following inoculation, the populations of Pf-AZS1 in non-transgenic and sense pflp-transgenic tobacco were lees than $5 \times 10^{5} \mathrm{cfu} / \mathrm{cm}^{2}$ at $3 \mathrm{dpi}$. However, this reached $1 \times 10^{8} \mathrm{cfu} / \mathrm{cm}^{2}$ when the antisense pflp-transgenic tobacco was inoculated with Pf-AZS1 under the same conditions (Fig. 5). In addition, no apparent symptoms of necrosis were observed in any of the Pf-AZS1-inoculated plants (data not shown).

To study the role of harpin in PFLP-mediated resistance, the sense pflp-transgenic tobacco was inoculated with harpin defective

A

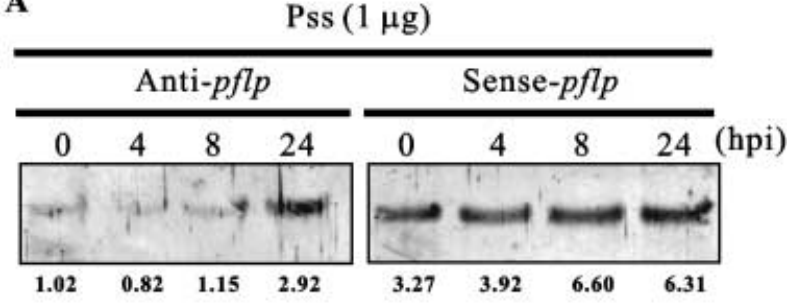

B

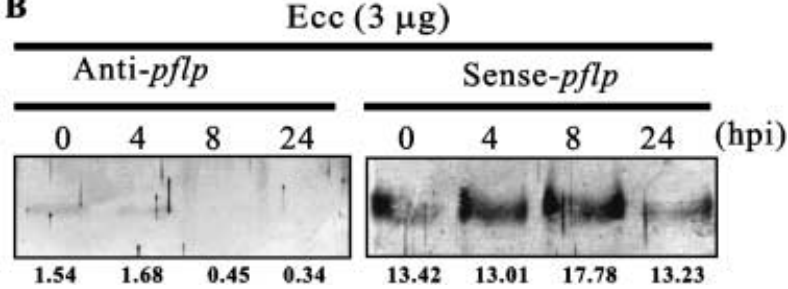

Fig. 4 The quantity of total Fd-l in inoculated pflp-transgenic tobacco. Bacterial suspensions $\left(1.0 \times 10^{5} \mathrm{cfu} / \mathrm{mL}\right)$ of $P$. syringae pv. syringae (Pss) or $E$. carotovora ssp. carotovora $(E c c)$ were infiltrated into the sense-pflp or anti-pflp transgenic tobacco, respectively. Total proteins of the inoculated leaf were extracted and analysed by Western blotting with antiserum against PFLP. One microgram protein was used in Western blots of Pss-treated plants (A) and $3 \mu \mathrm{g}$ for Ecc-treated plants (B). Signal intensity is noted below.

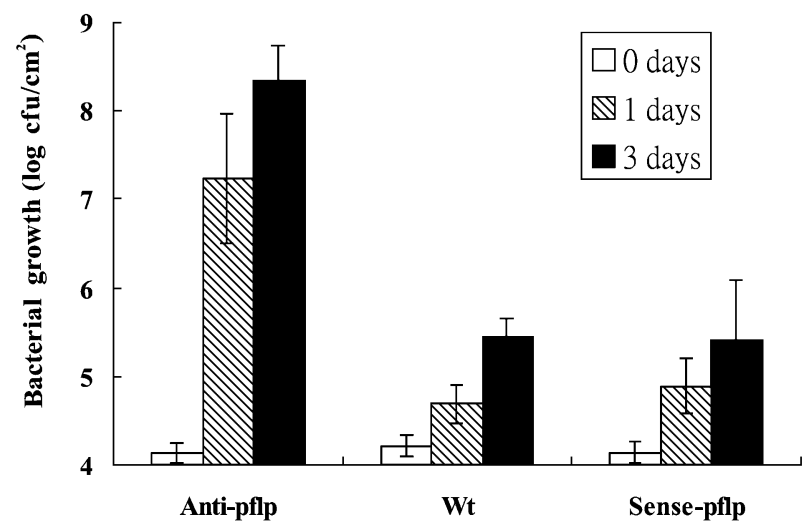

Fig. 5 P. fluorescens inoculated in the pflp-transgenic tobacco. The leaves of antisense $p f / p$, sense $p f / p$-transgenic and wild-type tobacco were infiltrated with $100 \mu \mathrm{L}$ of a bacterial suspension $\left(1.0 \times 10^{5} \mathrm{cfu} / \mathrm{mL}\right)$ of $P$. fluorescens AZS1. The bacterial populations inside inoculated tissue were detected at successive times post-inoculation. All values represent means of 16 replications with standard deviations shown as error bars.

strain E. carotovora ssp. carotovora AC5082 (EccAC5082) (Cui et al., 1996; Mukherjee et al., 1997). EccAC5082 was able to propagate as well as the wild E. carotovora ssp. carotovora in non-transgenic tobacco. The wild strain of E. carotovora ssp. carotovora was inhibited below $5 \times 10^{4} \mathrm{cfu} / \mathrm{cm}^{2}$ in sense pflptransgenic tobacco at $3 \mathrm{dpi}$. However, the population of EccAC5082 in inoculated sense pflp-transgenic tobacco reached $5 \times 10^{6} \mathrm{cfu} / \mathrm{cm}^{2}$ under the same conditions (Fig. 6).

\section{Phosphorylation of PFLP by harpin-activated kinase}

PFLP contains a putative CK2 phosphorylation site in the Cterminal region (Dayakar et al., 2003). To study the phosphorylation

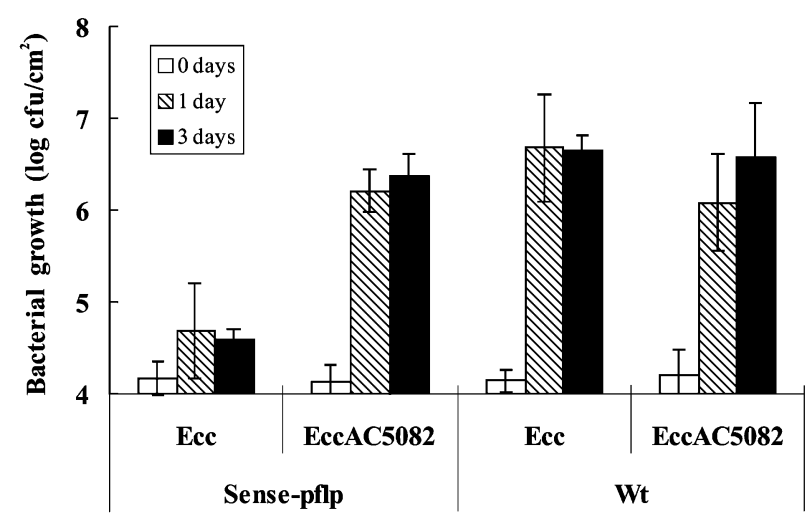

Fig. 6 The harpin-defective strain E. carotovora ssp. carotovora AC5082 inoculated in sense pflp-transgenic tobacco. The sense pflp-transgenic and non-transgeic tobaccos were inoculated with $100 \mu \mathrm{L}$ of a bacterial suspension $\left(1.0 \times 10^{5} \mathrm{cfu} / \mathrm{mL}\right)$ of $E$. carotovora ssp. carotovora (Ecc) or harpin-defective strain (EccAC5082), respectively. The bacterial populations were detected at successive times post-inoculation. All values represent means of 16 replications with standard deviations shown as error bars. 
of PFLP, an in vitro kinase assay was performed. A crude extract of harpin-treated tobacco contains several unidentified kinases with molecular weights of 39, 46, 49 and $58 \mathrm{kDa}$ that were able to phosphorylate myelin basic protein (MBP) at 30 min after the harpin treatment (Fig. 7A). The recombinant PFLP and its mutant protein $A 549$, whose carboxyl-terminal region was deleted from the 120th to the 144th residue, were used to substitute MBP as a substrate for the in vitro kinase assay. These harpin-activated kinases were able to phosphorylate PFLP but not A549 in the in vitro kinase assay (Fig. 7B).

\section{DISCUSSION}

The quantity of Fd-I found in plants is altered by various biotic and abiotic events (John et al., 1997; Kim et al., 2006; Mazouni et al., 2003; Vorst et al., 1993; Zou et al., 2005). The result in Fig. $1 \mathrm{~A}$ shows that $P$. syringae pv. syringae was able to increase levels of $\mathrm{Fd}-\mathrm{I}$ in inoculated plants. This phenomenon occurred not only in the wild-type tobacco but also in both sense and antisense pflp-transgenic tobacco (Fig. 4). As Fd-I is a major element of the photosynthesis-associated proteins that catalyse electron flow in photosynthesis, it would thus be reasonable to assume that

A

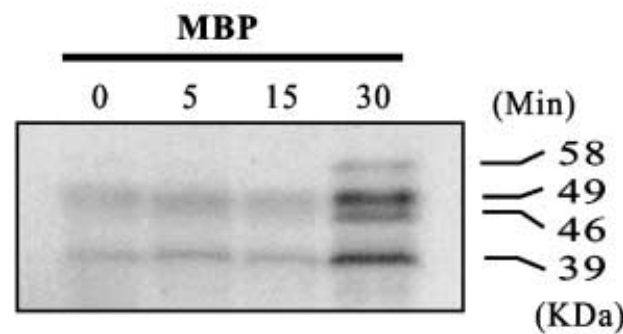

B

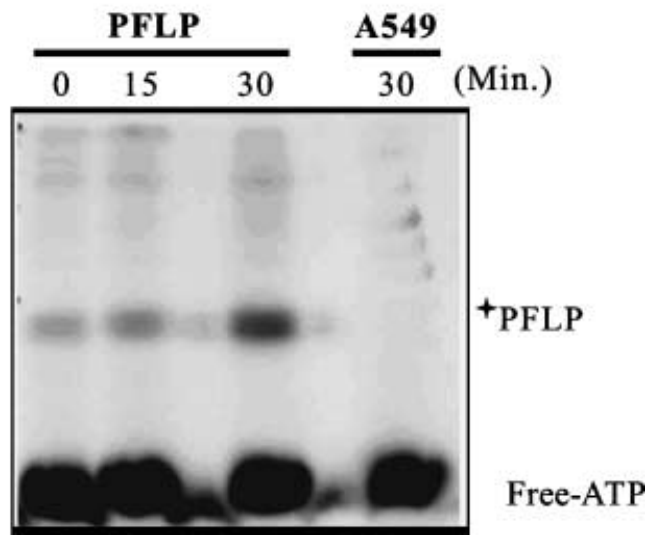

Fig. 7 Phosphorylation assay of recombinant PFLP in vitro. The crude extract of harpin-treated plant was run in the SDS-PAGE containing myelin basic protein (MBP). This gel was reacted with $\left[\gamma^{-32}\right.$ ]ATP and exposed to film (A). The crude extract was incubated with recombinant PFLP $(10 \mu \mathrm{g})$ or its C-terminal truncated mutant protein (PFLP-A549) in $50 \mu \mathrm{m}\left[\gamma^{-32}\right.$ P]ATP for $1 \mathrm{~h}$. This mixture was run in the SDS-PAGE and exposed to film. PFLP is indicated with a star and redundant $\left[\gamma^{-32}\right.$ P]ATP is indicated as Free-ATP (B). variations in Fd-I levels in plants would influence the generation of AOS under stressful conditions (Tognetti et al., 2006). We hypothesized that plants can activate the defence mechanism by changing levels of Fd-I when responding to pathogen attack. To test this hypothesis, detached leaf discs with various Fd-I levels were inoculated with $P$. syringae pv. syringae. However, the results indicated that the $P$. syringae pv. syringae could not infect detached leaf discs of antisense pflp-transgenic tobacco (Fig. 3). This might be due to the $50 \%$ suppression of $\mathrm{Fd}-\mathrm{I}$ in the antisense pflp-transgenic plant, which is insufficient to abolish the plant's defence capability. The other reason might be that inoculation of $P$. syringae pv. syringae in antisense pflp-transgenic tobacco would enhance the expression of $\mathrm{Fd}-\mathrm{I}$ although it was postponed for $24 \mathrm{~h}$ (Fig. 4A). This might be insufficient to abolish the plant disease resistance induced by $P$. syringae pv. syringae.

Decreasing photosynthesis-associated proteins of the host plant that are required for production of AOS might initially be important for pathogens to infect the host. For example, the PSI subunit protein PsaD of potato was decreased by $E$. carotovora ssp. carotovora (Montesano et al., 2004). The results in Fig. 1B indicate that $\mathrm{Fd}-\mathrm{I}$ of inoculated tobacco was also reduced by E. carotovora ssp. carotovora. This decrease was not due to the collapse of the host tissue because total proteins isolated from the inoculated plant were still intact within 24 hpi. Accordingly, we expect that expression of the antisense pflp gene in reducing the quantity of native Fd-I in transgenic tobacco might benefit the infection of E. carotovora ssp. carotovora. Surprisingly, however, propagation of E. carotovora ssp. carotovora in antisense pflp-transgenic plants was similar to that in wild-type tobacco (Fig. 3). It may be that E. carotovora ssp. carotovora is able to decrease levels of Fd-I of infected plants by itself (Fig. 4B). Thus, an artificial reduction of $\mathrm{Fd}-\mathrm{I}$ in antisense pflp-transgenic tobacco is not necessary for E. carotovora ssp. carotovora. By contrast, the saprophytic bacterium Pf-AZS1 was also used to challenge the antisense $p f l p$-transgenic tobacco. This was able to propagate well in antisense pflp-transgenic tobacco but not in the wild-type and sense pflp transgenic tobacco (Fig. 5). Pf-AZS1 may not propagate well in the non-transgenic tobacco due to the native quantity of $\mathrm{Fd}-\mathrm{I}$ in tobacco, so artificially reducing $\mathrm{Fd}-\mathrm{I}$ would enable Pf-AZS1 to grow well in the antisense pflp-transgenic tobacco.

Changes in Fd-I levels in plants may alter many fundamental metabolic processes (Geigenberger et al., 2005; Meyer, 2001). For example, reduction of $\mathrm{Fd}-\mathrm{I}$ in transgenic potato results in a reduced photosynthetic efficiency and distribution of electrons (Holtgrefe et al., 2003). In this study, a 50\% reduction in Fd-I quantity in antisense pflp-transgenic tobacco resulted in dwarf plants. By contrast, a threefold increase in $\mathrm{Fd}$-I did not change the appearance of sense pflp-transgenic tobacco (Fig. 2). We also attempted to obtain transgenic tomato lines with higher or lower Fd-I levels than used in tobacco here. However, it was difficult to 
find such transformants because most are chlorotic and lethal. This might result from the fact that the Fd/PS I ratio is strictly restricted and a change in one of them would constitute a lethal condition (Holtgrefe et al., 2003).

Many kinases are activated during the HR. For example, harpin was able to activate a 49-kDa harpin-activated protein kinase in tobacco (HAPK) (Adam et al., 1997). It also is able to activate the AtMPK4 (43 kDa) and AtMPK6 (47 kDa) in Arabidopsis (Desikan et al., 2001; Samuel et al., 2005). The fungal elicitin is able to activate kinases with molecular weights of 48,44 and $40 \mathrm{kDa}$ in tobacco (Zhang et al., 2000). In the present study, four kinases with molecular weights of $39,46,49$ and $58 \mathrm{kDa}$ were activated by harpin treatment (Fig. 7A). These unidentified kinases were able to phosphorylate PFLP (Fig. 7B). This result implies that phosphorylation of PFLP might occur when a plant responds to pathogen attack with harpin. To confirm the role of harpin in PFLP-raised resistance, the harpin mutant strain E. carotovora ssp. carotovora AC5086 was inoculated into the sense pflp-transgenic tobacco. The result shows that sense pflp-transgenic tobacco is only resistant to wild-type $E$. carotovora ssp. carotovora but not the harpin mutant strain (Fig. 6). These results imply that phosphorylation of PFLP by harpin-activated kinase might be involved in the activation of plant defence.

Activation of plant disease resistance through phosphorylation is known to be effective (Asai et al., 2002; Espinosa et al., 2003). The consequence of this phosphorylation is uncertain, but one possibility is that the phosphorylation of Fd-I involves protein travelling from the cytoplasm to the chloroplast (May and Soll, 2000; Waegemann and Soll, 1996; Su et al., 2001). In the present study, the signal peptide-truncated PFLP was expressed in the cytoplasm of transgenic tobacco. This transgenic tobacco was resistant to E. carotovora ssp. carotovora. However, we cannot say with certainty that PFLP travelling from the cytoplasm to the chloroplast is unnecessary because PFLP exhibits an antimicrobial ability in vitro (Huang et al., 2006). By contrast, CK2-phosphorylation would increase protein tolerance to proteases such as caspase (Meggio and Pinna, 2003). Caspase is activated by harpin and is involved in initiation of the HR (Chichkova et al., 2004). PFLP contains a CK2 phosphorylation site in the C-terminal region (Dayakar et al., 2003). Deletion of this C-terminal region would lead to increased PFLP instability (Huang et al., 2006). Thus, phosphorylation of PFLP might increase its tolerance to protease. The third possibility is that the phosphorylated status of Fd-I would affect the activity of other metabolic enzymes. For example, the enzymatic activity of 25 -hydroxyvitamin D-1 $\alpha$-hydroxylase, a key enzyme in the two-step activation process of vitamin $D$ to 1,25-dihydroxyvitamin $\mathrm{D}$, was regulated by phosphorylated Fd (Nemani et al., 1989).

In summary, we have demonstrated that Fd-I levels are regulated during pathogen infection. The amount of $\mathrm{Fd}-\mathrm{I}$ might influence the behaviour of the bacterial pathogen in transgenic plants. This resistance was dependent on the harpin, which was able to activate certain kinases to phosphorylate PFLP in vitro. These results imply that $\mathrm{Fd}-\mathrm{I}$ is involved in the determination of plant-microbe interactions. More information regarding the role of $\mathrm{Fd}-\mathrm{I}$ in plant disease resistance needs to be gathered.

\section{EXPERIMENTAL PROCEDURES}

\section{Agrobacterium-mediated transformation}

The coding sequence of the sweet-pepper ferredoxin ( $p f \mid p)$ gene was amplified by PCR using the following primers: B5SPF: 5'-CGGGATCCCGATGGCTAGTGTCTCAGCTACCA-3', and S3-PF: 5 '-CGAGCTCGTTAGCCCACGAGTTCTGCTTCT- $3^{\prime}$. The antisense pflp gene was amplified by primers B5-anti-SPF: $5^{\prime}$ CGGGATCCCGAATCGGGTGCTCAAGACGG-3' and S3-anti-PF: $5^{\prime}$ CGAGCTCGTACCGATCACAGATCGATGCA-3'. The PCR products were digested with $\mathrm{BamHI}$ and $\mathrm{SaCl}$, and were then inserted into the pBI121 vector (Clontech, Palo Alto, CA) to replace the coding sequence of GUS protein. The vector was verified and transferred into Agrobacterium tumefaciens C58C1 (Clontech), while the transformation of tobacco (Nicotiana tabacum cv. Xanthi) was performed by a standard leaf disc transformation method with A. tumefaciens C58C1 (Horsch et al., 1985). The independent transgenic lines of the transgenic tobaccos were self-fertilized before their seeds were collected.

\section{Growing conditions of the plants and bacteria}

All plants were grown in a growth chamber $(16 \mathrm{~h}$ light $/ 8 \mathrm{~h}$ dark at $30^{\circ} \mathrm{C}$ ). The irradiance of the chamber was $48 \mu \mathrm{mol} / \mathrm{m}^{2} / \mathrm{s}$. P. syringae pv. syringae strain 61 (provided by Dr H. C. Huang) (He et al., 1993), E. carotovora ssp. carotovora strain 71, E. carotovora ssp. carotovora strain AC5082 (provided by Professor Arun K. Chatterjee, University of Missouri, Columbia) (Cui et al., 1996) and P. fluorescens (Pf-AZS1) (isolated from Taiwan, unpublished data) were cultured in nutrient broth liquid medium (Difco, Le Pont de Claix, France) at $28^{\circ} \mathrm{C}, 175$ r.p.m. for 1 day. Culture of $A$. tumefaciens was prepared at $28^{\circ} \mathrm{C}$ in YEB medium $(5 \mathrm{~g} / \mathrm{L}$ yeast extract, $10 \mathrm{~g} / \mathrm{L}$ tryptone, $5 \mathrm{~g} / \mathrm{L} \mathrm{NaCl}, 5 \mathrm{~g} / \mathrm{L}$ sucrose, $0.5 \mathrm{~g} / \mathrm{L} \mathrm{MgSO} \cdot \cdot 7 \mathrm{H}_{2} \mathrm{O}, \mathrm{pH} 7.0$ ) containing $50 \mu \mathrm{g} / \mathrm{mL}$ kanamycin and $50 \mu \mathrm{g} / \mathrm{mL}$ rifamycin.

\section{Western blot analyses}

Total proteins of the plant leaves were extracted by homogenization $(0.2 \mathrm{~g} / \mathrm{mL})$ in extraction buffer (50 mm Tris- $\mathrm{HCl}$, pH 8.0, $1 \%$ Triton X-100, 1 mm EDTA, and PMSF). Insoluble materials were removed by centrifugation $(20000 \mathrm{~g})$, while the protein concentration of samples was determined by using Coomassie Brilliant Blue (BioRad). Three micrograms or $1 \mu \mathrm{g}$ of PFLP proteins were used to run in $15 \%$ SDS-PAGE and detected by Western blots with antiserum 
against PFLP. The antiserum against PFLP was prepared from rabbit as described by Huang et al. (2004).

\section{Inoculation of bacterial pathogen in tobacco}

The fully expanded leaves of tobacco (80 days post-planting) were infiltrated with $100 \mu \mathrm{L}$ of bacterial suspension $\left(1.0 \times 10^{5} \mathrm{cfu} / \mathrm{mL}\right)$ through a 25-gauge needle. Each leaf disc ( $0.8 \mathrm{~cm}$ diameter) was punched off from the inoculated areas of an individual plant and then was incubated in phosphate buffer ( $\mathrm{pH} 7.0)$ at room temperature with irradiance of $48 \mu \mathrm{mol} / \mathrm{m}^{2} / \mathrm{s}$. The punched discs were photographed 2 days post-inoculation.

The bacterial population inside the leaf was calculated as follows. Leaf tissue was ground in $100 \mu \mathrm{L}$ sterilized water in a microfuge tube. The suspension was serially diluted with sterilized water and was then plated out on nutrient broth agar plates (Difco). Colonies were counted after 1 day of incubation at $30^{\circ} \mathrm{C}$.

\section{Kinase assay}

The in-gel kinase assay was performed as described previously (Zhang et al., 1993). Twenty micrograms of proteins extracted from the tobacco leaf were subjected to electrophoresis on a $10 \%$ polyacrylamide gel containing SDS and $0.25 \mathrm{mg} / \mathrm{L}$ bovine brain myelin basic protein (MBP; Sigma, St Louis, MO). Following electrophoresis, the gel was washed three times with washing buffer [ $25 \mathrm{~mm}$ Tris-HCl, pH 7.5, $0.5 \mathrm{~mm}$ DL-dithiothreitol (DTT), $0.1 \mathrm{~mm} \mathrm{Na}_{3} \mathrm{VO}_{4}, 5 \mathrm{~mm} \mathrm{NaF}, 0.5 \mathrm{mg} / \mathrm{mL}$ bovine serum albumin, $0.1 \%$ Triton $\mathrm{X}-100$ ] for $30 \mathrm{~min}$ at room temperature, followed by three washes with renaturation buffer $(25 \mathrm{~mm}$ Tris- $\mathrm{HCl}, \mathrm{pH} 8.0$, $1 \mathrm{~mm}$ DTT, $0.1 \mathrm{~mm} \mathrm{Na}_{3} \mathrm{VO}_{4}, 5 \mathrm{~mm} \mathrm{NaF}$ ) overnight at $4{ }^{\circ} \mathrm{C}$. The gel was then washed with reaction buffer $(25 \mathrm{~mm}$ Tris- $\mathrm{HCl}, \mathrm{pH}$ 8.0, $2 \mathrm{~mm}$ EGTA, $12 \mathrm{~mm} \mathrm{MgCl}, 1 \mathrm{~mm}$ DTT, $0.1 \mathrm{~mm} \mathrm{Na}_{3} \mathrm{VO}_{4}$ ) for $30 \mathrm{~min}$ at room temperature and then was incubated in $12.5 \mathrm{~mL}$ of reaction buffer containing $50 \mu \mathrm{m}$ ATP with $50 \mu \mathrm{Ci}\left[\gamma^{32}\right.$ P]ATP (Sigma) for $90 \mathrm{~min}$ at room temperature. The gel was again washed five times with washing solution $[5 \%(\mathrm{w} / \mathrm{v})$ trichloroacetic acid and 1\% (w/v) sodium pyrophosphate] and once with 5\% glycerol. It was then dried on to a Whatman 3MM paper (BDH-Merck, UK) before visualizing the kinase activity via autoradiography.

The phosphorylation of recombinant PFLP was analysed as follows. The extraction isolated from harpin-treated tobacco $(20 \mu \mathrm{g})$ was mixed with $10 \mu \mathrm{g}$ recombinant PFLP and $50 \mu \mathrm{M} \mathrm{Ci}$ $\left[\gamma^{32}\right.$ P]ATP (Sigma, Germany) in the reaction buffer $(25 \mathrm{~mm}$ Tris- $\mathrm{HCl}$, pH 8.0, $2 \mathrm{~mm}$ EGTA, $12 \mathrm{~mm} \mathrm{MgCl} 2,1 \mathrm{~mm}$ DTT, $0.1 \mathrm{~mm}$ $\mathrm{Na}_{3} \mathrm{VO}_{4}$ ). The samples were electrophoresed on $10 \%$ SDSpolyacrylamide gels after $1 \mathrm{~h}$ of incubation. Unincorporated radioactivity was subsequently removed by washing the gel for $5 \mathrm{~h}$ at room temperature with several changes of $5 \%(\mathrm{w} / \mathrm{v})$ trichloroacetic acid and $1 \%(\mathrm{w} / \mathrm{v})$ sodium pyrophosphate. The gel was dried on to a Whatman 3MM paper (BDH-Merck, UK) before visualizing the kinase activity via autoradiography.

\section{Preparation of the recombinant protein}

E. coli M15 harbouring the pflp or pflp-A549 gene prepared in a previous study (Huang et al., 2006) was incubated in LB medium (Difco) with $100 \mu \mathrm{g} / \mathrm{mL}$ ampicillin and $25 \mu \mathrm{g} / \mathrm{mL}$ kanamycin at $37^{\circ} \mathrm{C}$, respectively. When the culture reached an absorbance of 0.6 at $A_{600}$, isopropylthio- $\beta$-D-galactoside induction was given to a final concentration of $1 \mathrm{~mm}$. Cells were then harvested after $4 \mathrm{~h}$ incubation at $37^{\circ} \mathrm{C}$, and the protein was purified with a Ni-NTA resin spin kit (Qiagen, Germany) in native conditions according to the manufacturer's instructions. The imidazole residue was removed by P6 gel spin column (Bio-Rad), and the eluting product was dialysed against a $10 \mathrm{~mm}$ sodium phosphate buffer (pH 7.0). Purified protein was analysed in $15 \%$ SDS-PAGE.

The recombinant harpin was produced as follows. The E. coli $\mathrm{DH} 5 \alpha$ harbouring the $h r p Z$ gene in plasmid pSY10 was provided by Dr H. C. Huang (National Chung-Hsien University, Taiwan) (He et al., 1993). The E. coli DH5 $\alpha$ harbouring plasmid pSY10 was grown overnight in LB medium containing $50 \mu \mathrm{g} / \mathrm{mL}$ ampicillin at $37^{\circ} \mathrm{C}$. Protein expression was induced by $1 \mathrm{~mm}$ isopropylthio$\beta$-D-galactoside for $4 \mathrm{~h}$ from which the protein was harvested in $10 \mathrm{~mm}$ phosphate buffer (pH 6.5) and then boiled for $10 \mathrm{~min}$. Meanwhile, the supernatants were collected by centrifugation $(10000 \mathrm{~g})$ before desalting by dialysis against a $10 \mathrm{~mm}$ sodium phosphate buffer (pH 7.0).

\section{ACKNOWLEDGEMENTS}

We would like to thank Prof. Arun K. Chatterjee of the University of Missouri, Columbia, for providing the harpin Ecc clone, E. carotovora ssp. carotovora strain 71 , and the harpin defective mutant, E. carotovora ssp. carotovora strain AC5082. We would also like to thank Dr Ming-Che Shih of the University of lowa and Dr Chao-Wen Wang of the University of California, Berkeley, for their critical review of this manuscript. This work was supported by grants to T.-Y.F. from the Academia Sinica and the National Science Council of Taiwan, Republic of China.

\section{REFERENCES}

Adam, A.L., Pike, S., Hoyos, M.E., Stone, J.M., Walker, J.C. and Novacky, A. (1997) Rapid and transient activation of a myelin basic protein kinase in tobacco leaves treated with harpin from Erwinia amylovora. Plant Physiol. 115, 853-861.

Arnon, D.I. (1989) The discovery of ferredoxin: the photosynthetic path. Trends Biochem. Sci. 13, 30-33.

Asai, T., Tena, G., Plotnikova, J., Willmann, M.R., Chiu, W.L., GomezGomez, L., Boller, T., Ausubel, F.M. and Sheen, J. (2002) MAP kinase signalling cascade in Arabidopsis innate immunity. Nature, 415, 977-983. 
Bertini, I., Luchinat, C., Provenzani, A., Rosato, A. and Vasos, P.R. (2002) Browsing gene banks for $\mathrm{Fe}_{2} \mathrm{~S}_{2}$ ferredoxins and structural modelling of 88 plant-type sequences: an analysis of fold and function. Proteins, 46, 110-127.

Chichkova, N.V., Kim, S.H., Titova, E.S., Kalkum, M., Morozov, V.S., Rubtsov, Y.P., Kalinina, N.O., Taliansky, M.E. and Vartapetian, A.B. (2004) A plant caspase-like protease activated during the hypersensitive response. Plant Cell, 16, 157-171.

Cui, Y., Madi, L., Mukherjee, A., Dumenyo, C.K. and Chatterjee, A.K. (1996) The RsmA- mutants of Erwinia carotovora subsp. carotovora strain Ecc71 overexpress hrp $\mathrm{E}_{\mathrm{Ecc}}$ and elicit a hypersensitive reactionlike response in tobacco leaves. Mol. Plant-Microbe. Interact. 9, 565573.

Curdt, I., Singh, B.B., Jakoby, M., Hachtel, W. and Bohme, H. (2000) Identification of amino acid residues of nitrite reductase from Anabaena sp. PCC 7120 involved in ferredoxin binding. Biochim. Biophys. Acta, $1543,60-68$

Dayakar, B.V., Lin, H.J., Chen, C.H., Ger, M.J., Lee, B.H., Pai, C.H., Chow, D., Huang, H.E., Hwang, S.Y., Chung, M.C. and Feng, T.Y. (2003) Ferredoxin from sweet pepper (Capsicum annuum L.) intensifying harpin $_{(\text {pss) }}$-mediated hypersensitive response shows an enhanced production of active oxygen species (AOS). Plant Mol. Biol. 51, 913-924.

Desikan, R., Hancock, J.T., Ichimura, K., Shinozaki, K. and Neill, S.J. (2001) Harpin induces activation of the Arabidopsis mitogen-activated protein kinases AtMPK4 and AtMPK6. Plant Physiol. 126, 1579-1587.

Elliott, R.C., Dickey, L.F., White, M.J. and Thompson, W.F. (1989) Cis-acting elements for light regulation of pea ferredoxin 1 gene expression are located within transcribed sequences. Plant Cell, 1, 691-698.

Espinosa, A., Guo, M., Tam, V.C., Fu, Z.Q. and Alfano, J.R. (2003) The Pseudomonas syringae type III-secreted protein HopPtoD2 possesses protein tyrosine phosphatase activity and suppresses programmed cell death in plants. Mol. Microbiol. 49, 377-387.

Geigenberger, P., Kolbe, A. and Tiessen, A. (2005) Redox regulation of carbon storage and partitioning in response to light and sugars. J. Exp. Bot. 56, 1469-1479.

Green, L.S., Yee, B.C., Buchanan, B.B., Kamide, K., Sanada, Y. and Wada, K. (1991) Ferredoxin and ferredoxin-NADP reductase from photosynthetic and nonphotosynthetic tissues of tomato. Plant Physiol. 96, 1207-1213.

Hanke, G.T., Kimata-Ariga, Y., Taniguchi, I. and Hase, T. (2004) A post genomic characterization of Arabidopsis ferredoxins. Plant Physiol. 134, 255-264.

He, S.Y., Huang, H.C. and Collmer, A. (1993) Pseudomonas syringae pv. syringae harpin $_{\text {Pss }}$ : a protein that is secreted via the Hrp pathway and elicits the hypersensitive response in plants. Cell, 73, 1255-1266.

Holtgrefe, S., Bader, K.P., Horton, P., Scheibe, R., von Schaewen, A. and Backhausen, J.E. (2003) Decreased content of leaf ferredoxin changes electron distribution and limits photosynthesis in transgenic potato plants. Plant Physiol. 133, 1768-1778.

Horsch, R.B., Fry, J.E., Hofmannn, N.L., Eichholtz, D., Rogers, S.G. and Fraley, R.T. (1985) A simple and general method for transferring genes into plants. Science, 227, 1229-1231.

Huang, H.E., Ger, M.J., Chen, C.Y., Yip, M.K., Chung, M.C. and Feng, T.Y. (2006) Plant ferredoxin-like protein (PFLP) exhibits an anti-microbial ability against soft-rot pathogen Erwinia carotovora subsp. carotovora in vitro and in vivo. Plant Sci. 171, 17-23.

Huang, H.E., Ger, M.J., Yip, M.K., Chen, C.Y., Pandey, A.K. and Feng, T.Y. (2004) A hypersensitive response was induced by virulent bacteria in transgenic tobacco plants overexpressing a plant ferredoxin-like protein (PFLP). Physiol. Mol. Plant Pathol. 64, 103-110.

John, I., Hackett, R., Cooper, W., Drake, R., Farrell, A. and Grierson, D. (1997) Cloning and characterization of tomato leaf senescence-related CDNAs. Plant Mol. Biol. 33, 641-651.

Joliot, P. and Joliot, A. (2006) Cyclic electron flow in C3 plants. Biochim. Biophys. Acta, 1757, 362-368.

Kang, H.G. and Klessig, D.F. (2005) Salicylic acid-inducible Arabidopsis CK2-like activity phosphorylates TGA2. Plant Mol. Biol. 57, 541-557.

Kim, M., Lee, S., Park, K., Jeong, E.J., Ryu, C.M., Choi, D. and Pai, H.S. (2006) Comparative microarray analysis of programmed cell death induced by proteasome malfunction and hypersensitive response in plants. Biochem. Biophys. Res. Commun. 342, 514-521.

Kimata, Y. and Hase, T. (1989) Localization of ferredoxin isoproteins in mesophyll and bundle sheath cells in maize leaf. Plant Physiol. 89, 11931197.

Kimata, Y., Matsumura, T., Kada, S., Fujimoto, H., Fujita, Y., Endo, T., Mano, J., Sato, T. and Hase, T. (2000) Differential electron floe around photosystem I by two C4-photsynthetic-cell-specific ferredoxins. EMBO J. 19, 5041-5050.

Liau, C.H., Lu, J.C., Prasad, V., Hsiao, H.H., You, S.J., Lee, J.T., Yang, N.S., Huang, H.E., Feng, T.Y., Chen, W.H. and Chan, M.T. (2003) The sweet pepper ferredoxin-like protein ( $p f l p)$ conferred resistance against soft rot disease in Oncidium orchid. Transgenic Res. 12, 329-336.

Matsumura, T., Kimata, A.Y., Sakakibara, H., Sugijama, T., Murata, H., Takao, T., Shimonishi, Y. and Hase, T. (1999) Complementary DNA cloning and characterization of ferredoxin localized in bundle-sheath cells of maize leaves. Plant Physiol. 119, 481-488.

May, T. and Soll, J. (2000) 14-3-3 Proteins form a guidance complex with chloroplast precursor proteins in plants. Plant Cell, 12, 53-64.

Mazouni, K., Domain, F., Chauvat, F. and Cassier-Chauvat, C. (2003) Expression and regulation of the crucial plant-like ferredoxin of cyanobacteria. Mol. Microbiol. 49, 1019-1029.

Meggio, F. and Pinna, L.A. (2003) One-thousand-and-one substrates of protein kinase CK2? FASEB J. 17, 349-368.

Meyer, J. (2001) Ferredoxins of the third kind. FEBS Lett. 509, 1-5.

Montesano, M., Scheller, H.V., Wettstein, R. and Palva, E.T. (2004) Down-regulation of photosystem I by Erwinia carotovora-derived elicitors correlates with $\mathrm{H}_{2} \mathrm{O}_{2}$ accumulation in chloroplasts of potato. Mol. Plant Pathol. 5, 115-123.

Morales, R., Frey, M. and Mouesca, J.M. (2002) An approach based on quantum chemistry calculations and structural analysis of a [2Fe-2S] ferredoxin that reveal a redox-linked switch in the electron-transfer process to the Fd-NADP+ ${ }^{+}$reductase. J. Am. Chem. Soc. 12, 67146722.

Mukherjee, A., Cui, Y., Liu, Y. and Chatterjee, A.K. (1997) Molecular characterization and expression of the Erwinia carotovora $\mathrm{hrpN}_{\mathrm{Ecc}}$ gene, which encodes an elicitor of the hypersensitive reaction. Mol. Plant-Microbe Interact. 10, 462-471.

Nemani, R., Ghazarian, J.G., Moorthy, B., Wongsurawat, N., Strong, R. and Armbrecht, H.J. (1989) Phosphorylation of ferredoxin and regulation of renal mitochondrial 25-hydroxyvitamin D-1 alphahydroxylase activity in vitro. J. Biol. Chem. 264, 15361-15366.

Onda, Y., Matsumura, T., Kimata-Ariga, Y., Sakakibara, H., Sugiyama, T. and Hase, T. (2000) Differential interaction of maize root ferredoxin: $\mathrm{NADP}^{+}$oxidoreductase with photosynthetic and non-photosynthetic ferredoxin isoproteins. Plant Physiol. 123, 1037-1045.

Samuel, M.A., Hall, H., Krzymowska, M., Drzewiecka, K., Hennig, J. 
and Ellis, B.E. (2005) SIPK signaling controls multiple components of harpin-induced cell death in tobacco. Plant J. 42, 406-416.

Su, Q., Schmid, K., Schild, C. and Boschetti, A. (2001) Effect of precursor protein phosphorylation on import into isolated chloroplasts from Chlamydomonas. FEBS Lett. 508, 165-169.

Tang, K.X., Sun, X.F., Hu, Q.N., Wu, A.Z., Lin, C.H., Lin, H.J., Twyman, R.M., Christou, P. and Feng, T.Y. (2001) Transgenic rice plants expressing the ferredoxin-like protein (AP1) from sweet pepper show enhanced resistance to Xanthomonas oryzae pv. oryzae. Plant Sci. 160, 10351042.

Tognetti, V.B., Palatnik, J.F., Fillat, M.F., Melzer, M., Hajirezaei, M.R., Valle, E.M. and Carrillo, N. (2006) Functional replacement of ferredoxin by a cyanobacterial flavodoxin in tobacco confers broad-range stress tolerance. Plant Cell, 18, 2035-2050.

Vorst, O., van Dam, F., Weisbeek, P. and Smeekens, S. (1993) Lightregulated expression of the Arabidopsis thaliana ferredoxin a gene involves both transcriptional and post-transcriptional processes. Plant J. 3, 793-803.

Waegemann, K. and Soll, J. (1996) Phosphorylation of the transit sequence of chloroplast precursor proteins. J. Biol. Chem. 271, 65456554.

Zhang, S., Jin, C.D. and Roux, S.J. (1993) Casein kinase Il-type protein kinase from pea cytoplasm and its inactivation by alkaline phosphatase in vitro. Plant Physiol. 103, 955-962.

Zhang, S., Liu, Y. and Klessig, D.F. (2000) Multiple levels of tobacco WIPK activation during the induction of cell death by fungal elicitins. Plant $\mathrm{J}$. 23, 339-347.

Zou, J., Rodriguez-Zas, S., Aldea, M., Li, M., Zhu, J., Gonzalez, D.O., Vodkin, L.O., DeLucia, E. and Clough, S.J. (2005) Expression profiling soybean response to Pseudomonas syringae reveals new defense-related genes and rapid HR-specific downregulation of photosynthesis. Mol. Plant-Microbe. Interact. 18, 1161-1174. 